\title{
Simulasi Perubahan Penggunaan Lahan Akibat Pembangunan Kawasan Industri Kendal (KIK) Berbasis Cellular Automata
}

\author{
${ }^{1}$ Muhammad Nur Sadewo dan ${ }^{2}$ Imam Buchori \\ ${ }^{1}$ ATR/BPN Kantor Pertanahan Kabupaten Badung, Bali, Indonesia \\ ${ }^{2}$ Magister Pembangunan Wilayah dan Kota, Universitas Diponegoro, Semarang, Indonesia \\ Email Koresponden: mnsadewo@gmail.com
}

Diterima: Januarai 2018 /Refisi: Februari 2018 Disetujui: September 2018

๑) 2018 Fakultas Geografi UGM dan Ikatan Geograf Indonesia (IGI)

\begin{abstract}
Abstrak. Kawasan industri Kendal (KIK) dikembangkan dengan luas mencapai 2.200 Ha di utara Kecamatan Kaliwungu yang berpotensi mengakselerasi pertumbuhan perkotaan, yang ditandai dengan proses urbanisasi dan konsumsi lahan yang tinggi. Penelitian ini bertujuan untuk melakukan prediksi penggunaan lahan tahun 2031 dengan pengaruh adanya KIK di Kendal Timur. Pendekatan yang digunakan yaitu kuantitatif berbasis raster, dengan analisis proyeksi perkembangan lahan terbangun berdasarkan trend perubahan penggunaan lahan tahun 2005 - 2017 dan kebutuhan lahan akibat KIK. Model simulasi menggunakan algorithma Cellular Automata (CA) dengan faktor pendorong meliputi faktor biofisik, sosial ekonomi, sarana prasarana, aksesbilitas dan ketetanggaan yang diturunkan menjadi 20 variabel. Hasil penelitian menunjukkan Model CA yang dibangun memiliki overall accuracy 95,68\% dan KIK memiliki pengaruh yang kuat untuk mempercepat pertumbuhan Kawasan Perkotaan Kaliwungu. Kedekatan jarak dengan KIK memiliki pengaruh terhadap arah perkembangan industri sebesar 24,10\%, gudang 21,60\%, permukiman 4,90\% dan perdagangan dan jasa 4,10\%. Arah perkembangan Kendal Timur tahun 2031 dominan terjadi di Kecamatan Kaliwungu kemudian menyebar di kecamatan lainnya dengan mengikuti pola perkembangan konsentris linier. Penggunaan lahan yang mengalami pertumbuhan tahun 2031 meliputi industri (2017,96 Ha), permukiman (1007,30 Ha), perdagangan dan jasa (271,39 Ha), dan gudang (18,76 Ha) yang diikuti terkonversinya lahan non terbangun yaitu tambak (1593,5 Ha), sawah irigasi $(784,35 \mathrm{Ha})$ kebun campuran $(362,34 \mathrm{Ha})$, tegalan $(361,65 \mathrm{Ha})$, tanah terbuka $(145,5 \mathrm{Ha})$, sawah tadah hujan $(66,71 \mathrm{Ha})$ dan hutan produksi $(1,32 \mathrm{Ha})$.
\end{abstract}

Kata kunci : cellular automata, kawasan industri, model, perubahan penggunaan lahan, simulasi.

\begin{abstract}
Developed within up to 2,200 ha of land in the north of Kaliwungu Sub-District, Kendal Industrial Park (KIK) is potential to accelerate the growth of the urban areas in Kendal Regency. It is characterized by the process of urbanization and it also will encourage high consumption of land. This study aims to predict land use in 2031 with the effect of KIK in Kendal Timur. The approach used was raster-based quantitative, analysed by measuring the land growth projection based on the trend of land use change between 2005 - 2017 and the land demand due to KIK. The simulation model exerted Cellular Automata (CA) algorithm with driving factors including biophysical, socioeconomic, facilities, accessibility, neighbourhood factors and spatial policy that were downgraded to 20 variables. The results showed that the built-in CA model had an overall accuracy of 95.68\% and KIK has a strong influence in improving the growth of Kaliwungu urban areas. Proximity to KIK has an influence on the direction of: industrial development of $24.10 \%$, warehouse of $21.60 \%$, settlements of $4.90 \%$ and commercial and services of $4.10 \%$. The direction of development in East Kendal will dominantly occur in Kaliwungu Sub-District then spread to other sub-districts by following concentric linear development pattern. Land use growing in 2031 includes industrial (2017.96 Ha), settlements $(1007,30 \mathrm{Ha})$, commercial and services $(271.39 \mathrm{Ha})$, and warehouses $(18,76 \mathrm{Ha})$, followed by the conversion of some land use consisted of coastal fishpond $(1.593,54 \mathrm{Ha})$, irrigated rice field $(784,35 \mathrm{Ha})$, mixed garden $(362,34 \mathrm{Ha})$, dry field $(361,65 \mathrm{Ha})$, open ground $(145,5 \mathrm{Ha})$, rainfed rice field $(66,71 \mathrm{Ha})$ and production forests $(1,32 \mathrm{Ha})$.
\end{abstract}

Keywords: cellular automata, industrial park, model, land-use change, simulation

\section{PENDAHULUAN}

Pertumbuhan perkotaan (urban growth) adalah proses spasial dan populasi multidimensi dimana kota dan permukiman perkotaan dianggap sebagai pusat fokus populasi karena fasilitas ekonomi dan sosial yang spesifik, yang merupakan komponen vital dalam pemenuhan kebutuhan manusia (Dadras, et al., 2015). Pertumbuhan kota dipercepat dengan meningkatnya populasi penduduk perkotaan yang diikuti perubahan ekonomi pedesaan dan gaya hidup semakin kekotaan seiring meningkatnya angkatan kerja yang bekerja di sektor non pertanian (Cohen, 2004). Reformasi ekonomi berperan penting dalam mempercepat pertumbuhan suatu kota dimana keterbukaan untuk investasi memiliki dampak langsung yang positif dalam pertumbuhan kota (Anderson \& Ge, 2004). Perluasan kota dapat diasosiasikan dengan biaya lingkungan yang spesifik dalam hal ini konsumsi lahan dan mobilitas penduduk (Camagni, et al., 2002). Urbanisasi yang sangat cepat, konversi lahan pertanian menjadi lahan terbangun, merupakan faktor utama dari perubahan penggunaan/tutupan lahan dimasa depan (Han, Yang, \& Song, 2015). Perubahan penggunaan lahan nonpertanian dicirikan salah satunya oleh tumbuhnya 
kawasan industri (Tian, Ge, \& Li, 2017). Pertumbuhan industri merupakan salah satu hal yang menyebabkan terjadinya urbanisasi selanjutnya mempercepat dalam pertumbuhan dan perkembangan kota (Pawan, 2016). Migrasi pekerja menuju kawasan industriakan membuat proses urbanisasi semakin cepat yang secara otomatis diikuti perubahan penggunaan lahan disekitarnya.

Kawasan industri di Kabupaten Kendal berdasarkan Rencana Tata Ruang Wilayah (RTRW) Kabupaten Kendal Tahun 2011 - 2031 ditetapkan pengembangan dan pemantapan kawasan industri pesisir timur yaitu di PKL Perkotaan Kaliwungu dalam hal ini yaitu Kawasan Industri Kendal (KIK). Pengembangan kawasan industri meliputi industri besar, industri sedang dan kawasan industri kecil atau mikro. KIK dikembangkan oleh PT Jababeka Tbk dan Sembcorp Development Ltd dengan luas yang mencapai 2.200 Ha. Dikutip dari kompas.com 13 November 2016, pembangunan KIK akan menyerap total 500.000 pekerja dengan rincian 100.000 pekerja langsung dan 400.000 pekerja tak langsung. Penyerapan tenaga kerja ini tentunya akan diiringi dengan kebutuhan untuk permukiman yang akan berpengaruh besar dalam perubahan penggunaan lahan dari lahan pertanian untuk berubah menjadi lahan terbangun. Kawasan industri mendorong terjadinya urbanisasi dan perkembangan kota. Damayanti (2010) mengungkapkan bahwa kawasan industri sebagai generator kota dalam rangka pertumbuhan kota, karena dinegara berkembang sangat dipengaruhi oleh urbanisasi karena industrialisasi di kota.

Perubahan penggunaan lahan merupakan salah satu subyek penelitian utama perubahan lingkungan global dan pembangunan berkelanjutan (Guan et al., 2011). Perubahan penggunaan lahan di masa depan akan dicirikan oleh proses urbanisasi yang cepat dimana akan terjadi lahan bertransformasi menjadi lahan perkotaan yang terbangun (Han et al., 2015). Perubahan penggunaan lahan yang tidak terkendali dapat menimbulkan masalah sosial, ekonomi dan lingkungan (Wardana et al., 2016). Dalam rangka mengantisipasi konversi lahan yang tidak terkontrol maka dibutuhkan perencanaan yang tepat sesuai dengan kebutuhan dimasa depan. Simulasi penggunaan lahan merupakan pendekatan populer untuk menguji kebijakan dan strategi dalam rangka mengurangi dampak dari pembangunan yang tidak diinginkan dengan beberapa skenario perencanaan (Hosseinali, et al., 2013). Pemodelan spasial penggunaan lahan dapat digunakan untuk melakukan analisis penggunaan lahan secara spasial dalam periode waktu tertentu dan diprediksikan distribusi spasial perubahan penggunaan lahannya. Pemodelan juga memungkinkan perencana dan pengambil kebijakan disuatu wilayah dan kota untuk mempelajari suatu masalah dibeberapa tingkatan yang berbeda. Dengan mendekati sistem dengan tingkatan masalah yang lebih tinggi, perencana diberikan kesiapan lebih baik untuk dapat memahami perilaku dan interaksi suatu unsur tingkat tinggi dalam suatu sistem dan siap untuk mengatasi permasalahan dan kompleksitas keseluruhan sistem (Santé, García, Miranda, \& Crecente, 2010). Berikut adalah alur dalam proses pemodelan (Gambar 1).

Cellular Automata (CA) adalah sistem dinamika diskrit dimana ruang dibagi kedalam bentuk spasial sel teratur dan waktu berproses pada setiap tahapan yang berbeda Wolfram (1984). CA merupakan salah satu metode terbaik saat ini dalam melakukan simulasi spasial, termasuk simulasi penggunaan lahan dengan kemampuannya mengakomodasi pendekatan trend dan target (Pratomoatmojo, 2014). Model CA telah berkembang untuk simulasi pertumbuhan kota karena kesederhanaan, fleksibilitas dan intuitifnya, dan terutama karena kemampuan menggabungkan dimensi spasial dan temporal (Santé et al., 2010). Kemajuan dalam teknik pemodelan spasial-temporal, khususnya pengembangan model berbasis CA telah terbukti efisien dalam simulasi pertumbuhan daerah perkotaan (Leao, Bishop, \& Evans, 2014). Torrens (2003) menyatakan bahwa CA dapat digunakan untuk melakukan simulasi penggunaan lahan, dan perubahan populasi penduduk yang dimodelkan dalam sebuah sel. Sel tersebut dalam secara efektif menggabungkan data ekonomi, demografis dan transportasi. Menurut Liu \& He (2009) terdapat 5 elemen dasar dari cellular automata yaitu:

1. Sel (cell) merupakan unit dasar spasial dalam ruang seluler. Sel tersebut dapat berbentuk square yang menjadi dasar analisis dalam suatu pemodelan perkembangan kota dan perubahan penggunaan lahan.

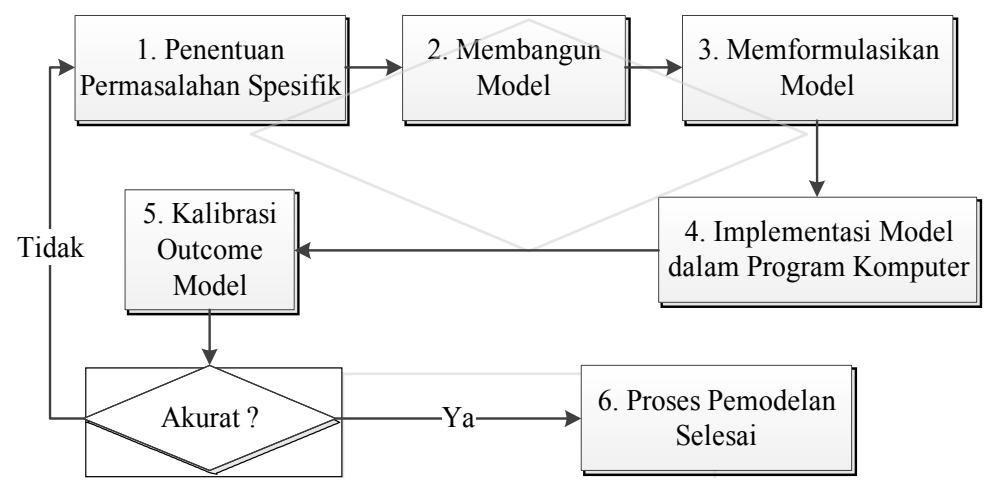

Gambar 1. Tahapan Proses Pemodelan (Caldwell dan Ram (1999) dalam Liu, 2009) 
2. Kondisi (state), adalah mendefinisikan atribut dari suatu sistem. Setiap sel hanya dapat mengambil satu kondisi dari serangkaian kondisi pada waktu tertentu (misal mewakili jenis penggunaan lahan).

3. Ketetanggaan (neighbourhood), yang merupakan serangkaian sel yang saling berinteraksi untuk menghasilkan suatu nilai sel yang baru.

4. Aturan transisi (transition rules), adalah suatu ketentuan bagaimana perubahan suatu jenis penggunaan lahan dengan mempertimbangkan kondisi saat ini dan kondisi sel tetangganya.

5. Waktu (time-step), adalah variabel yang menentukan dimensi waktu yang digunakan selama proses perhitungan dan dapat didefinisikan sebagai periode iterasi.

Dalam pemodelan penggunaan lahan perlu diperhatikan faktor - faktor yang mempengaruhi perubahan suatu penggunaan lahan tertentu baik faktor fisik, faktor ekonomi dan faktor sosial. Simulasi penggunaan lahan akan mencapai realistis apabila faktor sosial ekonomi dan dimensi spasial dan temporal terintegrasi dalam proses simulasi (Milad et al, 2016). Adanya interaksi berbagai faktor baik ekonomi, politik, lingkungan, biofisik, kelembagaan dan budaya menjadi tantangan dengan tingkat kesulitan dalam mengidentifikasi dan mengevaluasi perubahan penggunaan lahan (Maria et al, 2014). Menurut Verburg, et al (2005 dalam Bogaert \& Dendoncker, 2007) terdapat 5 faktor utama yang berpengaruh dalam perubahan penggunaan lahan yaitu : 1) Faktor biofisik (potensi dan penghambat), 2) Faktor ekonomi, 3) Faktor sosial, 4) Kebijakan tata ruang, dan 5) Interaksi keruangan dan karakteristik ketetanggaan.

Pembangunan KIK di Kecamatan Kaliwungu tentunya akan memberikan dampak yang signifikan baik perekonomian, sosial, dan tata guna lahan. Kebutuhan lahan yang tinggi akan mempercepat konversi lahan pertanian menjadi lahan terbangun. Hal ini tentunya harus dapat direncanakan penggunaan lahannya agar tidakterjadipembangunan yang sporadik (urbansprawl) dan dapat mengancam lahan pertanian. Penelitian ini bertujuan untuk melakukan prediksi penggunaan lahan tahun 2031 dengan pengaruh adanya KIK di Kendal Timur dengan Algorithma Cellular Automata dan Sistem Informasi Geografis (SIG).

\section{METODE PENELITIAN}

Pendekatan penelitian yang digunakan dalam penelitian ini yaitu pendekatan kuantitatif dengan basis spasio temporal dengan data raster dan unit analisis piksel. Adapun ukuran piksel yang digunakan dalam proses simulasi yaitu 10 x $10 \mathrm{~m}$. Penelitian ini dilakukan di Kendal Timur yang terdiri atas 5 kecamatan yaitu Kecamatan Kaliwungu, Kota Kendal, Kaliwungu Selatan, Brangsong, dan Ngampel sebagai wilayah yang berpotensi terpengaruh langsung dengan adanya pembangunan KIK. Adapun variabel penelitian yang digunakan sebagai variabel pendorong (driving forces) dan penghambat (constraint variable) perubahan penggunaan lahan adalah sebagai berikut (Tabel 1).

Tabel 1. Variabel Penelitian

\begin{tabular}{|c|c|c|}
\hline No & Faktor & Variabel \\
\hline \multirow{5}{*}{1} & & Jarak ke Kemiringan Lereng \\
\hline & Biofisik & Jarak terhadap Rawan Bencana \\
\hline & & Jarak ke sungai \\
\hline & & Jarak ke pusat kota \\
\hline & & Jarak ke pusat pemerintahan \\
\hline \multirow[t]{4}{*}{2} & Sosial Ekonomi & Jarak ke pusat perdagangan \\
\hline & & Jarak ke Kawasan Industri Kendal (KIK) \\
\hline & & Jarak ke pelabuhan \\
\hline & & Jarak ke fasilitas peribadatan \\
\hline \multirow[t]{4}{*}{3} & Sarana dan Prasarana & Jarak ke fasilitas pendidikan \\
\hline & & Jarak ke fasilitas kesehatan \\
\hline & & Jarak ke jalan arteri \\
\hline & & Jarak ke jalan kolektor \\
\hline \multirow[t]{4}{*}{4} & Aksesbilitas & Jarak ke jalan lokal \\
\hline & & Jarak ke jalan kereta api \\
\hline & & Jarak Rencana Interchange Jalan Tol \\
\hline & & Permukiman \\
\hline \multirow{3}{*}{5} & Ketetanggaan (Kedekatan dengan & Perdagangan dan Jasa \\
\hline & lahan terbangun eksisting) & Industri \\
\hline & & Perkantoran \\
\hline 6 & Kebijakan Tata Ruang & $\begin{array}{l}\text { Kawasan Lindung (sempadan pantai, sempadan sungai, sempadan } \\
\text { jalan kereta api dan kawasan LP2B) }\end{array}$ \\
\hline
\end{tabular}

Sumber : Hasil Kajian Pustaka, 2017

144| https://jurnal.ugm.ac.id/mgi 
Pengumpulan data dilakukan dengan observasi lapangan, wawancara, kuesioner dan survei instansi. Observasi lapangan dilakukan untuk uji interpretasi penggunaan lahan, wawancara pakar/ahli (expert judgement) pada stakeholder penataan ruang untuk menilai pembobotan variabel yang berpengaruh terhadap jenis perubahan penggunaan lahan dengan metode AHP.

Tahapan analisis yang dilakukan dalam penelitian ini meliputi (Gambar 2):

1. Analisis Perubahan Penggunaan Lahan

Perubahan penggunaan lahan dianalisis berdasarkan peta penggunaan lahan tahun 2005 dan peta penggunaan lahan tahun 2017. Peta penggunaan lahan tersebut diturunkan dari citra penginderaan jauh resolusi tinggi dengan metode interpretasi digitizing on screen dengan data dasar yang digunakan untuk interpretasi penggunaan lahan yaitu Citra Quickbird (Digital Globe) tahun 2005 dan Citra CNES/Airbus tahun 2017 untuk penggunaan lahan tahun 2017. Hasil analisis perubahan penggunaan lahan kemudian diperoleh data jenis penggunaan lahan yang mengalami pertumbuhan atau yang berkurang luasannya, yang kemudian dapat dihitung pola pertumbuhan lahan terbangun tiap tahunnya untuk melakukan prediksi penggunaan lahan tahun 2031. Klasifikasi penggunaan lahan yang digunakan dalam penelitian ini merupakan klasifikasi dari Danoedoro (2006) tingkat 2 dengan beberapa penyesuaian.

2. Analisis Perhitungan Kebutuhan Lahan Akibat Pembangunan KIK

Kebutuhan lahan sebagai efek berganda akibat pembangunan KIK dalam hal ini kebutuhan lahan permukiman dan fasilitas umum dan sosial dihitung berdasarkan Permenperin No. 40 Tahun 2016 tentang Pedoman Teknis Pembangunan
Kawasan Industri. Untuk fasilitas umum dan sosial dijustifikasi sebagai perdagangan dan jasa dalam penelitian ini.

3. Analisis Pemodelan Perubahan Penggunaan Lahan

Analisis ini bertujuan membangun model simulasi penggunaan lahan untuk memprediksi penggunaan lahan di masa depan dengan melakukan serangkaian proses simulasi dengan menggunakan variabel - variabel yang berpengaruh terhadap perubahan suatu jenis penggunaan lahan. Cellular Automata memegang peranan penting dalam proses pembangunan model selain variabel variabel yang berpengaruh dalam perubahan suatu jenis penggunaan lahan. Dalam pemodelan dengan cellular automata, suatu sel penggunaan lahan akan berubah menjadi sel penggunaan lahan lain dengan berbagai aturan (transition rules) yang ditetapkan. Model simulasi penggunaan lahan menggunakan perangkat lunak LanduseSim 2.3.1 yang berbasis Cellular Automata.

Prinsip fundamental dari cellular automata dapat digambarkan sebagai berikut :

$S_{x_{i j}}^{t+1}=f\left(S_{\Omega_{x_{i j}}}^{t} S_{x_{i j}}^{t+1}=f\left(S_{\Omega_{x_{i j}}}^{t}\right)\right.$

Dimana $S_{x_{i i}}^{t+1} S_{x_{i j}}^{t+1}$ adalah keadaan sel $x_{i j} x_{i j}$ pada waktu $\mathrm{t}+1 ; \Omega_{x_{i j}} \Omega_{x_{i j}}$ mewakili satu set sel dilingkungan tertentu (termasuk sel itu sendiri); $S_{\Omega_{x_{i j}}^{t}} S_{\Omega_{x_{i j}}}$ mewakili satu set sel $\Omega_{x_{i j}} \Omega_{x_{i j}}$ pada waktu t; dan $f f$ merupakan fungsi seperangkat aturan transisi.

Adapun tahapan dalam pembangunan model simulasi penggunaan lahan dalam penelitian ini sebagai berikut.

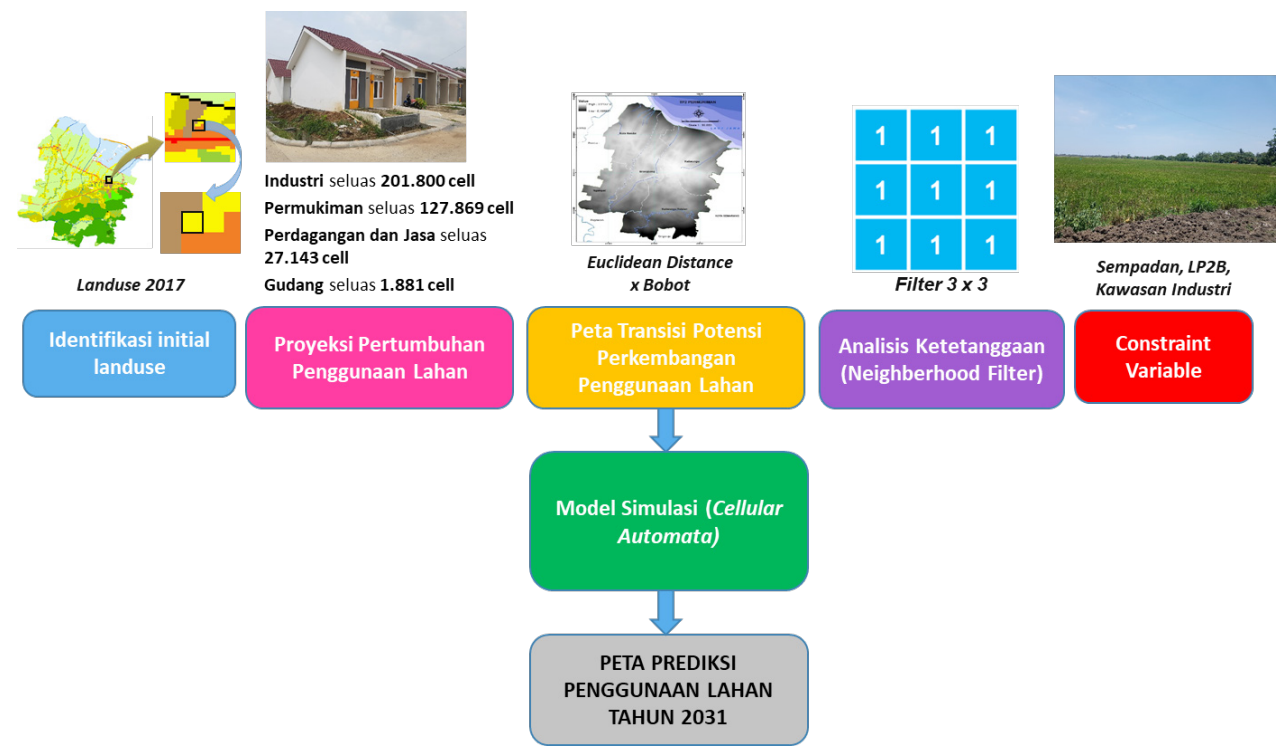

Gambar 2. Tahapan Pembangunan Model Simulasi Penggunaan Lahan 


\section{HASIL DAN PEMBAHASAN}

\section{Perubahan Penggunaan Lahan}

Hasil klasifikasi penggunaan lahan yaitu cagar alam, gudang, hutan produksi, industri, jalan, kebun campuran, kuburan, lapangan, pelabuhan, perdagangan dan jasa, perkantoran, permukiman, pesisir, rel kereta api, sawah irigasi, sawah tadah hujan, sungai, RTH, tambak, tanah terbuka, tegalan, TPA, dan jalan tol. Uji hasil ketelitian pemetaan dilakukan dengan membandingkan hasil interpretasi penggunaan lahan tahun 2017 dengan hasil cek lapangan berdasarkan sampel yang telah ditentukan sebelumnya. Perhitungan ketelitian hasil interpretasi dalam penelitian ini menggunakan formula yang dikemukakan oleh short (1982 dalam Purwadhi, 2001). Dari hasil perhitungan diperoleh nilai ketelitian pemetaan hasil interpretasi adalah sebesar $91,23 \%$.

Hasil analisis perubahan pengguaan lahan menunjukkan bahwa selama periode tahun 2005 hingga tahun 2017 terjadi pertumbuhan dan pengurangan luasan pada jenis penggunaan lahan tertentu (Tabel 2, Gambar 3). Peningkatan luasan tertinggi terjadi pada jenis penggunaan lahan permukiman sebesar 260,65 Ha, diikuti tanah terbuka sebesar 128,61 Ha, jalan tol sebesar 104,91 Ha, industri sebesar 54,65 Ha, perdagangan dan jasa seluas $28,87 \mathrm{Ha}$, gudang seluas 16,13 Ha, RTH sebesar 1,93 Ha, dan perkantoran sebesar 1,17 Ha. Secara spasial perubahan penggunaan lahan tersebut didominasi pada Kawasan Perkotaan
Kaliwungu dan Kawasan Perkotaan Kota Kendal terutama untuk permukiman, tanah terbuka, industri, perdagangan dan jasa, gudang dan perkantoran. Tanah terbuka memiliki perkembangan yang cukup signifikan, akan tetapi setelah dilakukan survei lapangan tanah terbuka tersebut merupakan lahan siap bangun baik itu untuk perumahan maupun untuk pabrik/industri. Untuk permukiman juga terdapat penambahan pada wilayah selatan yang meliputi kecamatan kaliwungu selatan dan ngampel walau tidak signifikan.

Dengan peningkatan luasan lahan terbangun tersebut diatas memiliki konsekuensi terjadinya penurunan luas pada jenis penggunaan lahan lainnya. Penurunan luas tertinggi terjadi pada jenis penggunaan lahan sawah irigasi sebesar $235,54 \mathrm{Ha}$, diikuti tegalan sebesar 125,28 Ha, tambak sebesar 112,24 Ha, dan kebun campuran sebesar 65,92 Ha. Penurunan luas ini terjadi karena berubah menjadi lahan terbangun antara lain permukiman, industri, perdagangan dan jasa, gudang dan sebagainya. Sawah irigasi yang terdampak paling tinggi dominan berubah menjadi permukiman yaitu seluas $128,94 \mathrm{Ha}$, tanah terbuka $36,39 \mathrm{Ha}$, industri 22,26 Ha, perdagangan dan jasa sebesar 12,62 Ha dan sebagainya. Tegalan juga banyak terkonversi untuk permukiman sebesar 77,44 Ha. Adapun tambak banyak berubah menjadi tanah terbuka (lahan siap bangun untuk industri) sebesar 92,02 Ha dan industri sebesar 21,79 Ha. Kebun campuran juga terkonversi dominan untuk permukiman yaitu seluas 55,25 Ha.

Tabel 2. Matriks transisi penggunaan lahan di Kendal Timur tahun 2005 dan 2017, dalam Ha

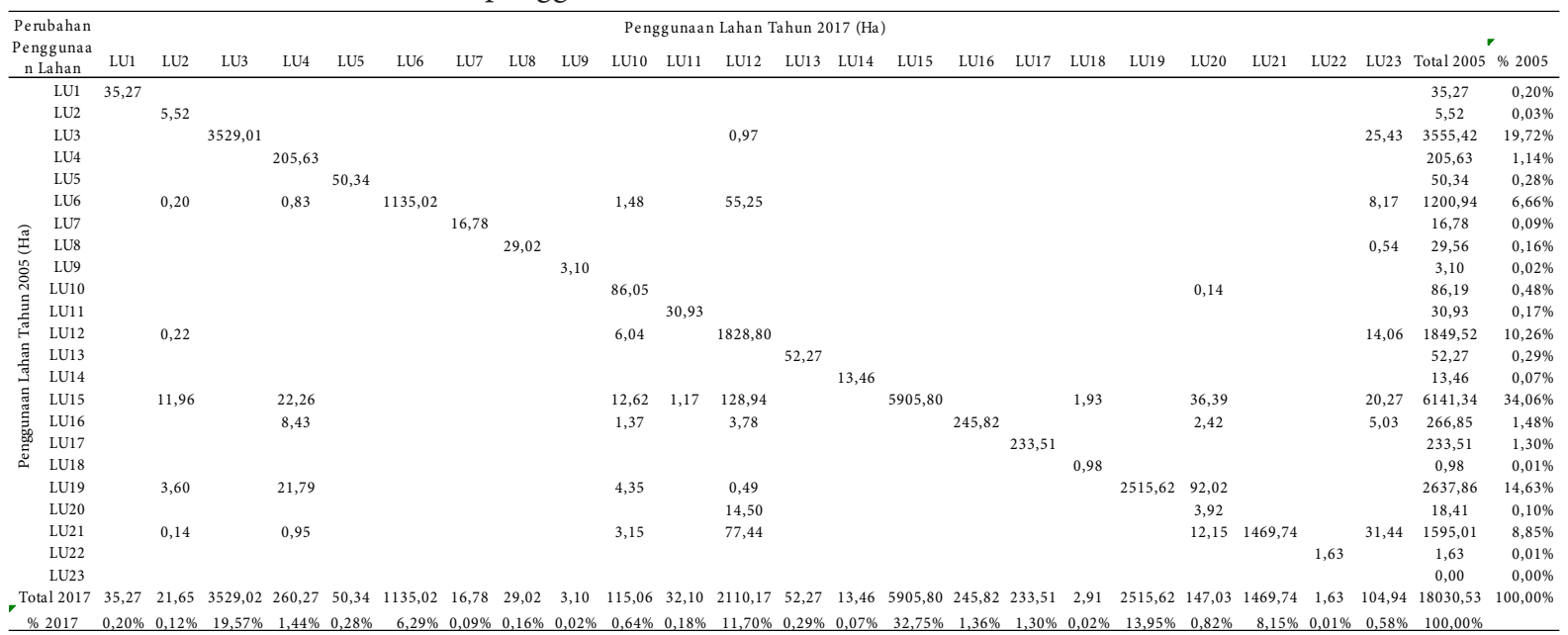

Sumber: Hasil analisis, 2017

Ket:LU1 (Cagar Alam), LU2 (Gudang), LU3 (Hutan Produksi), LU4 (Industri), LU5 (Jalan), LU6 (Kebun Campuran), LU7 (Kuburan), LU8 (Lapangan), LU9 (Pelabuhan), LU10 (Perdagangan dan Jasa), LU11 (Perkantoran), LU 12 (Permukiman), LU13 (Pesisir), LU14 (Rel Kereta Api), LU15 (Sawah Irigasi), LU16 (Sawah Tadah Hujan), LU17 (Sungai), LU18 (RTH), LU19 (Tambak), LU20 (Tanah Terbuka), LU21 (Tegalan), LU22 (TPA), LU23 (Jalan Tol) 


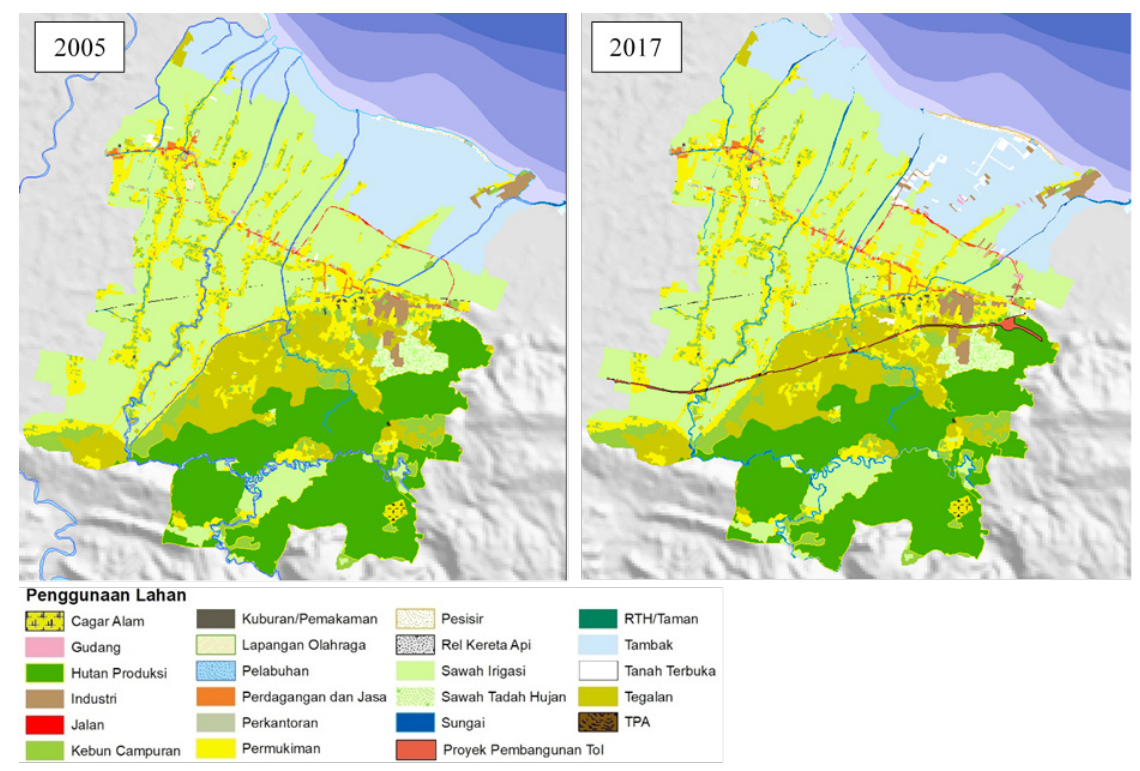

Gambar 3. Perbandingan Penggunaan Lahan Tahun 2005 Dan 2017

Laju perubahan penggunanan lahan 2031 diproyeksikan berdasarkan hasil analisis penggunaan lahan tahun 2005 dan 2017. Dalam hasil analisis terjadi beberapa pertumbuhan penggunaan lahan antara lain gudang, industri, permukiman, perdagangan dan jasa, perkantoran, RTH/taman, tanah terbuka dan pembangunan tol. Dalam penelitian ini pertumbuhan penggunaan lahan pada tahun 2031 dibatasi pada penggunaan lahan yang memiliki sifat dinamis dan dominan yang disesuaikan dengan kondisi wilayah penelitian yaitu adanya penetapan kawasan strategis ekonomi yaitu kawasan industri. Sifat dinamis dalam hal ini yaitu jenis penggunaan lahan yang akan terus bertumbuh dengan tidak adanya intervensi atau sedikit intervensi dari pengambil kebijakan. Dominan dalam hal ini yaitu perubahan luasan jenis penggunaan lahan yang terjadi secara dominan diwilayah penelitian berdasarkan hasil analisis secara time series yaitu tahun 2005 dan tahun 2017. Berdasarkan pembatasan tersebut maka dalam proses analisis proyeksi penggunaan lahan tahun 2031 maka dibatasi pada pertumbuhan jenis penggunaan lahan yaitu gudang, industri, perdagangan dan jasa, dan permukiman. Adapun laju pertumbuhan per tahun untuk keempat jenis penggunaan lahan tersebut (dalam sel 10x10m) yaitu gudang $134 \mathrm{sel}$, industri 452 sel, perdagangan dan jasa 242 sel, dan permukiman 2345 sel.

\section{Proyeksi Pertumbuhan Lahan Tahun 2031}

Proyeksi pertumbuhan lahan tahun 2031 di Kendal Timur dilakukan dengan melakukan penjumlahan tiap jenis penggunaan lahan yang mengalami pertumbuhan baik yaitu hasil analisis laju perubahan penggunaan lahan tahun 2005 - 2017 dan kebutuhan lahan akibat pembangunan KIK. Hal tersebut dikecualikan untuk pertumbuhan industri dimana pada hasil analisis laju perubahan penggunaan lahan tidak disertakan dalam perhitungan karena diasumsikan sudah tercover dalam luasan rencana kawasan industri sesuai dengan RTRW Kabupaten Kendal yaitu seluas 2.200 Ha. Hal ini didasari bahwa perkembangan industri baru di Kabupaten Kendal hanya diperbolehkan diwilayah yang ditetapkan sebagai kawasan industri di sisi utara Kecamatan Kaliwungu dan Kecamatan Brangsong. Nilai pertumbuhan pada tiap jenis penggunaan lahan ini kemudian akan digunakan sebagai dasar untuk melakukan simulasi perubahan penggunaan lahan tahun 2031 di Kendal Timur. Berikut adalah proyeksi pertumbuhan penggunaan lahan tahun 2031 di Kendal Timur (Tabel 3).

Tabel 3. Proyeksi Pertumbuhan Lahan Tahun 2031, dalam sel (10x10m)

\begin{tabular}{clccc}
\hline & & \multicolumn{2}{c}{ Proyeksi Pertumbuhan Penggunaan Lahan (sel 10 x 10 m) } \\
\cline { 3 - 5 } No. Jenis Penggunaan Lahan & $\begin{array}{c}\text { Analisis Laju Perubahan } \\
\text { Penggunaan Lahan }\end{array}$ & $\begin{array}{c}\text { Analisis Kebutuhan } \\
\text { Lahan Akibat } \\
\text { Pembangunan KIK }\end{array}$ & Total Pertumbuhan \\
\hline 1 & Permukiman & 32.829 & 95.040 & 127.869 \\
2 & Perdagangan dan Jasa & 3.383 & 23.760 & 27.143 \\
3 & Industri & 6.329 & 201.800 & 201.800 \\
4 & Gudang & 1.881 & - & 1.881 \\
& Total Luas & 44.422 & 250.800 & 358.693 \\
\hline
\end{tabular}

Sumber: Hasil analisis, 2017 
Potensi Transisi Perkembangan Penggunaan Lahan

Tahap pertama yaitu menentukan jangkauan faktor pendorong perubahan penggunaan lahan. Nilai jarak jangkauan atau juga disebut dengan kedekatan dengan suatu faktor pendorong akan menentukan arah perubahan suatu jenis penggunaan lahan tertentu, dimana suatu faktor pendorong dapat memiliki pengaruh yang berbeda pada setiap jenis penggunaan lahan yang berbeda. Suatu jenis penggunaan lahan memiliki potensi berubah dengan semakin dekat dengan suatu faktor pendorong, dapat pula semakin jauh dengan suatu faktor pendorong berpotensi terjadi perubahan penggunaan lahan tertentu. Analisis ini dilakukan dengan menggunakan tools Euclidean
Distance yang terdapat pada Software ArcGIS. 10.3. (Gambar 5).

Tahap kedua yang menentukan nilai pengaruh (bobot) variabel pendorong yang telah ditetapkan menggunakan analisis AHP yang didasarkan kuesioner pada stakeholder terpilih (expert judgement). Stakeholder yang dipilih merupakan yang memiliki peran dan ahli dalam bidang tata ruang meliputi akademisi dan stakeholder yang berkaitan dengan tata ruang dan industri di Kabupaten Kendal. Berikut adalah hasil perhitungan penentuan nilai bobot untuk masing - masing faktor pendorong perubahan penggunaan lahan (Tabel 4).

Tabel 4. Nilai pengaruh (bobot) faktor pendorong perubahan penggunaan lahan

\begin{tabular}{clcccc}
\hline \multirow{2}{*}{ No. } & \multicolumn{2}{c}{ Faktor Pendorong } & \multicolumn{3}{c}{ Nilai Pengaruh (Bobot) } \\
\cline { 3 - 5 } & & Gudang & Industri & Perdagangan dan Jasa & Permukiman \\
\hline 1 & Jarak Ke Kemiringan Lereng Datar & $4,90 \%$ & $3,70 \%$ & $3,80 \%$ & $4,60 \%$ \\
2 & Jarak Ke Sungai & $1,40 \%$ & $1,30 \%$ & $0,90 \%$ & $1,20 \%$ \\
3 & Jarak Ke Rawan Bencana & $1,40 \%$ & $1,10 \%$ & $1,00 \%$ & $1,50 \%$ \\
4 & Jarak Ke Pusat Kota & $4,10 \%$ & $3,00 \%$ & $4,10 \%$ & $7,10 \%$ \\
5 & Jarak Ke Pusat Pemerintahan & $3,70 \%$ & $2,70 \%$ & $2,40 \%$ & $6,00 \%$ \\
6 & Jarak Ke Pusat Perdagangan & $2,50 \%$ & $3,10 \%$ & $3,50 \%$ & $3,80 \%$ \\
7 & Jarak Ke Pelabuhan & $\mathbf{1 2 , 9 0 \%}$ & $\mathbf{1 5 , 0 0 \%}$ & $1,10 \%$ & $1,80 \%$ \\
8 & Jarak Ke KIK & $\mathbf{2 1 , 6 0 \%}$ & $\mathbf{2 4 , 1 0 \%}$ & $4,10 \%$ & $4,90 \%$ \\
9 & Jarak Ke Fasilitas Peribadatan & $1,90 \%$ & $1,30 \%$ & $1,80 \%$ & $1,50 \%$ \\
10 & Jarak Ke Fasilitas Pendidikan & $2,10 \%$ & $1,90 \%$ & $3,10 \%$ & $4,60 \%$ \\
11 & Jarak Ke Fasilitas Kesehatan & $3,20 \%$ & $3,20 \%$ & $2,40 \%$ & $2,70 \%$ \\
12 & Jarak Ke Jalan Arteri & $7,90 \%$ & $\mathbf{1 3 , 0 0 \%}$ & $\mathbf{2 2 , 4 0 \%}$ & $4,20 \%$ \\
13 & Jarak Ke Jalan Kolektor & $3,00 \%$ & $4,20 \%$ & $7,80 \%$ & $4,20 \%$ \\
14 & Jarak Ke Jalan Lokal & $1,60 \%$ & $2,30 \%$ & $3,70 \%$ & $\mathbf{1 4 , 2 0 \%}$ \\
15 & Jarak Ke Jalan Kereta Api & $1,50 \%$ & $1,30 \%$ & $1,70 \%$ & $1,70 \%$ \\
16 & Jarak Ke Interchange Jalan Tol & $\mathbf{1 1 , 3 0 \%}$ & $3,90 \%$ & $4,60 \%$ & $5,30 \%$ \\
17 & Jarak Ke Permukiman & $1,10 \%$ & $1,30 \%$ & $6,00 \%$ & $\mathbf{1 6 , 4 0 \%}$ \\
18 & Jarak Ke Perdagangan dan Jasa & $2,20 \%$ & $1,90 \%$ & $\mathbf{1 7 , 8 0 \%}$ & $6,60 \%$ \\
19 & Jarak Ke Industri & $\mathbf{1 0 , 1 0 \%}$ & $\mathbf{1 0 , 3 0 \%}$ & $3,20 \%$ & $4,50 \%$ \\
20 & Jarak Ke Perkantoran & $1,60 \%$ & $1,50 \%$ & $4,30 \%$ & $3,20 \%$ \\
\hline
\end{tabular}

Sumber : Hasil analisis, 2017

Tahap selanjutnya yaitu menentuhan potensi transisi perkembangan penggunaan lahan untuk mengetahui lokasi mana yang berpotensi untuk perkembangan suatu jenis penggunaan lahan tertentu berdasarkan variabel pendorong yang telah dilakukan analisis euclidean distance dan nilai pengaruh (bobot) untuk masing - masing variabel pendorong tersebut. Berikut analisis potensi transisi perkembangan penggunaan lahan digambarkan secara diagramatis.

Setiap nilai sel pada growth potential akan menunjukkan potensi suatu perkembangan/perubahan untuk tiap jenis penggunaan lahan yang bertumbuh, dimana semakin besar nilai sel maka pada lokasi tersebut akan berpotensi terjadi perubahan, sebaliknya jika memiliki nilai yang semakin rendah lokasi tersebut tidak berpotensi untuk terjadi perubahan. Dapat dilihat pada Gambar 6 yang menunjukkan peta transisi perkembangan dimana semakin putih rona maka memiliki nilai sel yang tinggi sebaliknyajika jika semakin hitam memiliki nilai sel rendah. Perkembangan lahan gudang dan industri cenderung akan terjadi disisi utara kecamatan kaliwungu dimana terdapat kawasan industri dan jalan arteri lingkar kaliwungu, yang ditunjukan rona putih pada gambar transisi perkembangan gudang dan industri. Selain Jalan Lingkar Kaliwungu, gudang juga berpotensi berkembang di Jalan Raya Timur Kaliwungu hingga mendekati perbatasan dengan Kota Semarang. Sedangkan untuk perdagangan dan jasa, dan permukiman memiliki kecenderungan akan berkembang dimulai dari pusat Kecamatan Kaliwungu yang kemudian menyebar diwilayah sekitarnya yang memiliki rona keputihan. 


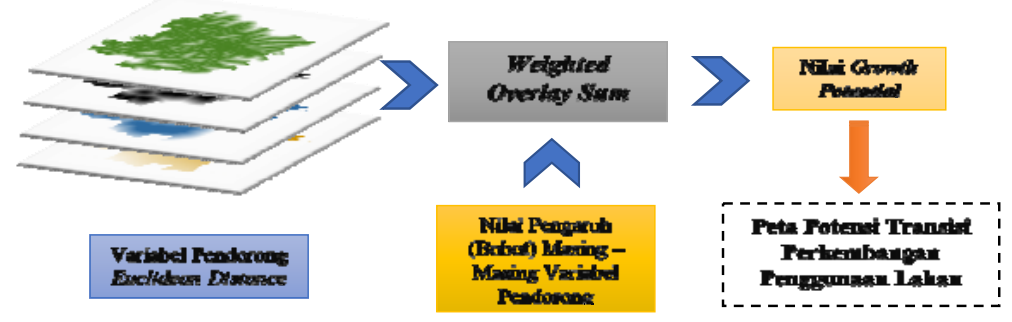

Gambar 5. Diagram analisis potensi transisi perkembangan penggunaan lahan
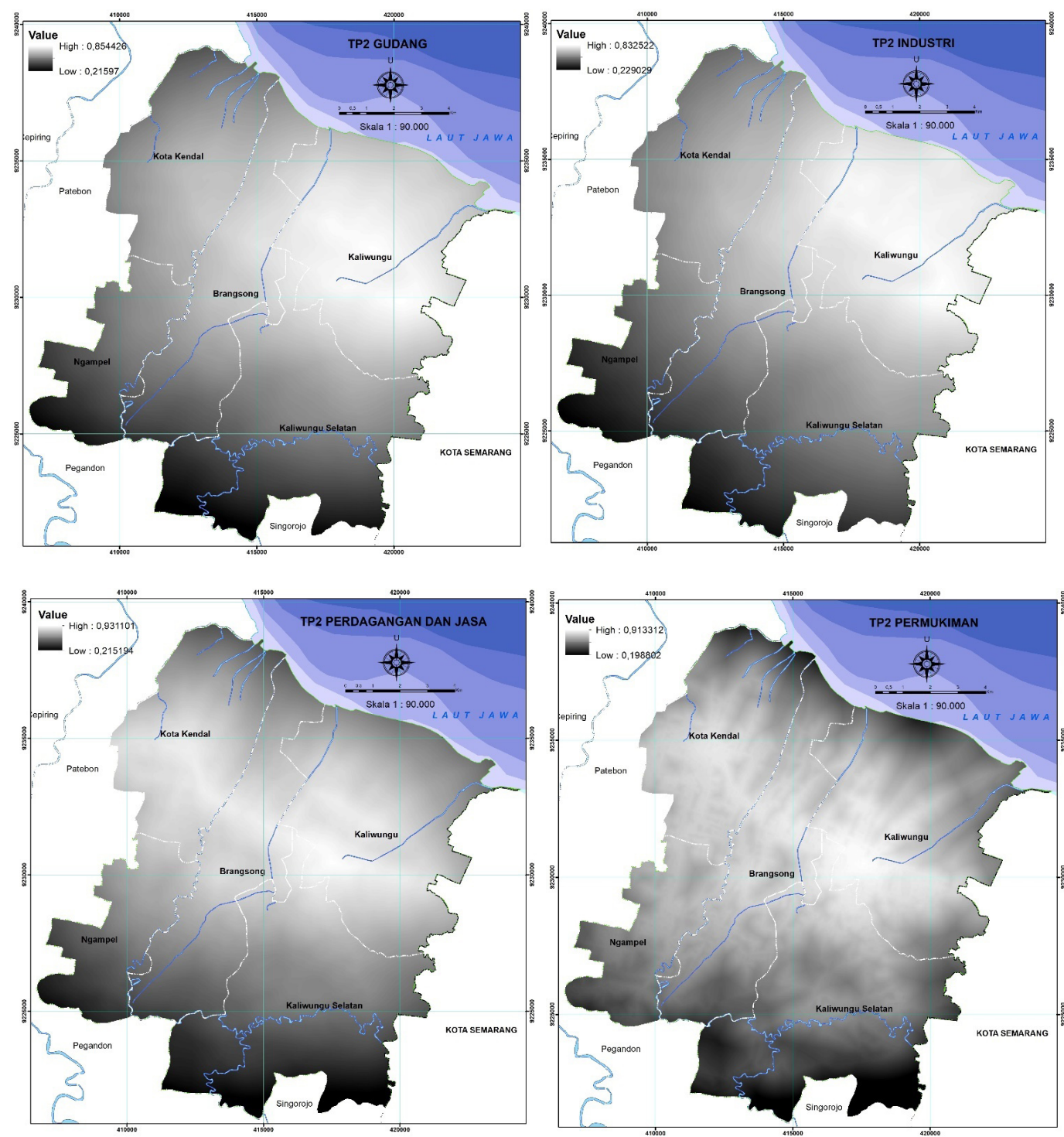

Gambar 6. Peta transisi perkembangan penggunaan lahan

\section{Ketetanggaan (Neighberhood Filter)}

Dalam penelitian ini menggunakan ukuran kernel filter 3x3 dengan mempertimbangkan wilayah penelitian yang cukup luas dan ukuran sel yang digunakan yaitu $10 \times 10 \mathrm{~m}$. Dengan penggunaan ukuran kernel $3 \times 3$ tersebut dirasa sudah mencukup untuk dapat mewakili nilai sel tetangga untuk menentukan nilai baru pada sel inti (Gambar 7).

\section{Constraint Variable}

Constraint variable untuk perkembangan penggunaan lahan gudang, industri, perdagangan dan jasa, dan permukiman yaitu kawasan sempadan dan kawasan LP2B. Kawasan sempadan meliputi sempadan pantai, sempadan sungai, dan sempadan jalan kereta api. Khusus untuk permukiman constraint variable ditambah dengan kawasan industri, dimana 


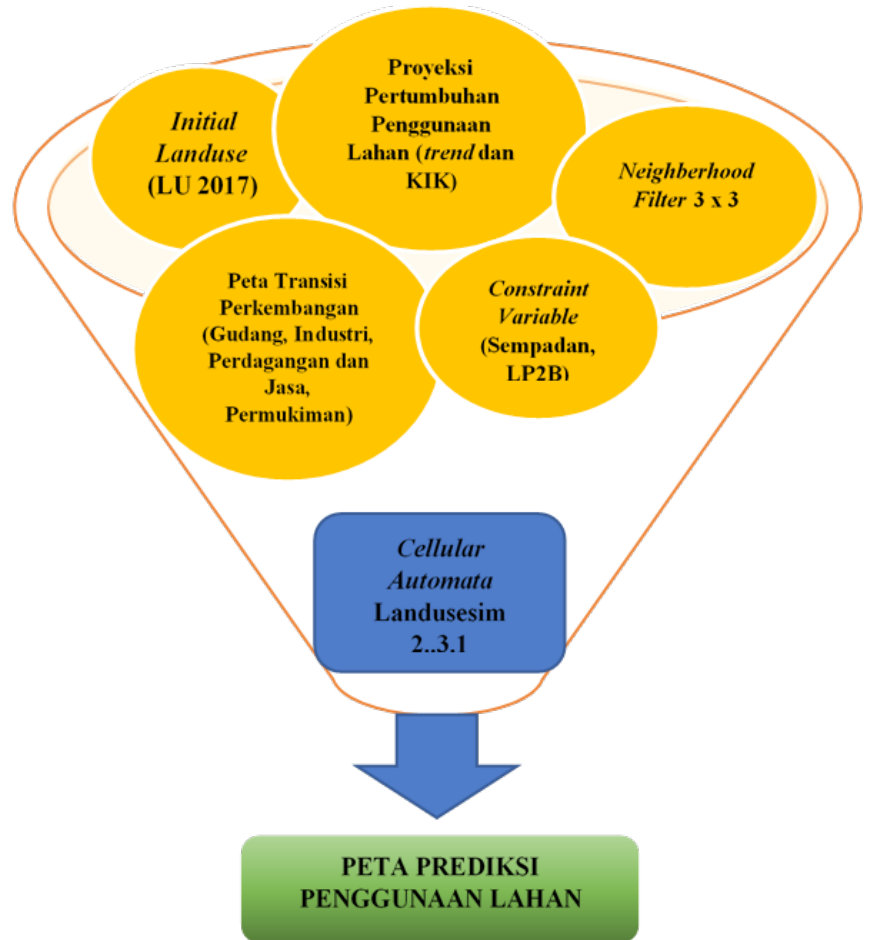

Gambar 7. Model simulasi perubahan penggunaan lahan

permukiman dibatasi tidak dapat berkembang didalam kawasan industri yaitu dalam hal ini KIK.

\section{Prediksi Penggunaan Lahan Tahun 2031 Kendal Timur}

Model simulasi perubahan penggunaan lahan dapat digambarkan dalam Gambar 6. Pemodelan dilakukan dengan software Landusesim 2.3.1 yang berbasis cellular automata dengan masukan LU 2017 sebagai initial landuse, nilai proyeksi pertumbuhan penggunaan lahan, neighberhood filter 3x3, constraint variable dan peta transisi perkembangan.

Validasi merupakan suatu tahapan penting dalam pemodelan. Model simulasi perubahan penggunaan lahan yang dibangun dilakukan analisis validasi model dengan melakukan simulasi penggunaan lahan tahun 2017 dengan initial landuse (T0) penggunaan lahan tahun 2005, dan kemudian dibandingkan dengan peta penggunaan lahan tahun 2017 hasil interpretasi untuk mengetahui tingkat akurasinya. secara umum hasil simulasi model tersebut telah memberikan gambaran yang sesuai dengan perkembangan penggunaan lahan periode tahun 2005 hingga 2017. Hasil analisis validasi menunjukkan nilai overall accuracy yang tinggi yaitu 95,68 \%. Dengan hasil akurasi yang tinggi tersebut kemudian model dapat dilakukan untuk analisis selanjutnya yaitu prediksi penggunaan lahan tahun 2031.

Hasil simulasi prediksi penggunaan lahan tahun 2031 menunjukkan bahwa perkembangan kota di Kendal Timur tidak dapat dilepaskan oleh tiga variabel utama 1) Adanya penetapan kawasan industri yang memberikan peluang besar masuknya industri industri besar di Kendal Timur. Pada akhir tahun 2017 telah terdapat 28 investor yang sudah bergabung di KIK dengan nilai investasi $\pm 4,4 \mathrm{~T}$ dengan potensi menyerap 4000 tenaga kerja. 2) Adanya Kawasan LP2B di Kabupaten Kendal melalui Perda Nomor 13 Tahun 2013 tentang perlindungan lahan pertanian pangan berkelanjutan di Kabupaten Kendal, merupakan kawasan yang harus dilindungi dan dikembangkan secara konsisten guna menghasilkan pangan pokok bagi kemandirian, ketahanan, dan kedaulatan pangan nasional. 3) Adanya proyek strategis nasional yaitu Jalan Tol Batang Semarang sepanjang $75 \mathrm{~km}$ yang melewati wilayah penelitian (Seksi IV Kendal kaliwungu) yang direncanakan akan beroperasi ditahun 2018 tentunya akan memberikan pengaruh yang cukup signifikan terutama di sekitar interchange jalan tol yang terdapat dibeberapa lokasi yaitu di Kecamatan Ngampel, Brangsong dan Kaliwungu.

Hasil analisis perbadingan antara peta penggunaan lahan tahun 2017 dan tahun 2031 diperoleh bahwa perkembangan industri dengan adanya penetapan kawasan industri di Kendal Timur dalam hal ini KIK meningkat dengan luasan tertinggi yaitu 2017,96 Ha atau meningkat sebesar 775,72\% dari tahun 2017. Perdagangan dan jasa dan permukiman sebagai penggunaan lahan yang terdampak dengan adanya KIK, meningkat signifikan pada tahun 2031 yaitu masing masing terjadi peningkatan untuk untuk permukiman sebesar 1007,30 $\mathrm{Ha}$ atau meningkat $47,74 \%$ dan perdagangan dan jasa 271,39 $\mathrm{Ha}$ atau meningkat 236,42 $\%$. Sedangkan penggunaan lahan gudang berkembang 
dengan luas $18,76 \mathrm{Ha}$ atau meningkat $86,73 \%$ dari luas tahun 2017. Hal ini mengindikasikan bahwa dengan adanya suatu kawasan industri disuatu wilayah akan memberikan multiplier effect untuk pertumbuhan penggunaan lahan terbangun lain dalam hal ini permukiman dan perdagangan dan jasa. Pertumbuhan penggunaan lahan terbangun diiringi dengan konversi atau perubahan penggunaan lahan non terbangun dengan luasan yang signifikan pula.

Penggunaan lahan non terbangun yang terkonversi dari tahun 2017 hingga tahun 2031 berdasarkan hasil prediksi penggunaan lahan tahun 2031 meliputi hutan produksi, kebun campuran, sawah irigasi, sawah tadah hujan, tambak, tanah terbuka, dan tegalan dengan luas yang bervariasi. Tambak menjadi penggunaan lahan yang terkonversi menjadi lahan terbangun tertinggi yaitu seluas $1.593,54 \mathrm{Ha}$ atau terjadi penurunan lahan tambak sebesar 63,35\% dari tahun 2017. Penggunaan lahan industri menjadi lahan terbangun terbesar yang mengkonversi lahan tambak, karena memang KIK diarahkan di bagian utara Kecamatan Kaliwungu yang merupakan lahan tambak. Penggunaan lahan tertinggi kedua yang terkonversi menjadi lahan terbangun yaitu sawah irigasi dengan luas 784,35 $\mathrm{Ha}$ atau berkurang sebesar 13,28\% dari lahan sawah irigasi pada tahun 2017. Konversi lahan sawah irigasi dapat dikatakan cukup ideal dan tidak terlalu signifikan dengan luas tersebut hingga tahun 2017, hal ini tidak lepas dari adanya batasan kawasan LP2B sehingga arahan lokasi lahan terbangun tidak dapat mengkoversi kawasan LP2B yang mayoritas merupakan sawah irigasi. Pada wilayah penelitian sawah irigasi dominan terkonversi menjadi permukiman yaitu dengan luas $438,27 \mathrm{Ha}$.

Selain lahan - lahan non terbangun yang terkonversi menjadi lahan terbangun terdapat pula pada hasil prediksi penggunaan lahan tahun 2031 lahan terbangun terkonversi menjadi lahan terbangun. Terdapat permukiman yang terkonversi menjadi perdagangan dan jasa dengan luas 190,85 Ha atau 70,32\% dari luas perkembangan perdagangan dan jasa tahun 2031 (Gambar 8, Tabel 5). Perkembangan perdagangan dan jasa yang merubah permukiman terjadi cukup luas di Kecamatan Kaliwungu. Hal ini dipengaruhi kondisi eksisting pusat kota kecamatan telah berkembang perdagangan dan jasa, kemudian dengan adanya KIK akan mengakselerasi perkembangan perdagangan dan jasa di pusat kota Kecamatan Kaliwungu tersebut.

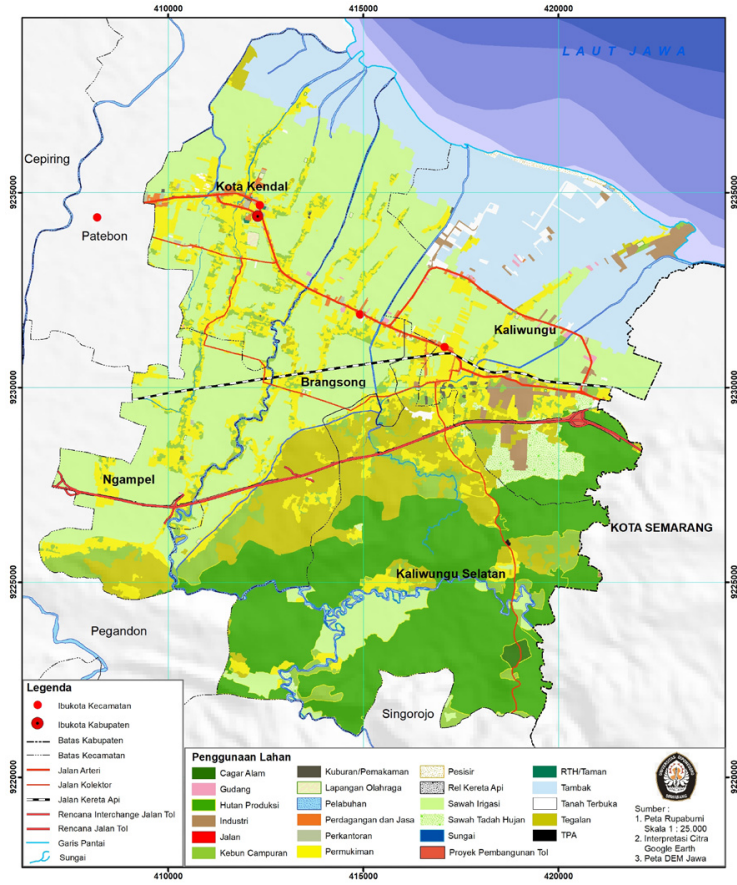

(a)

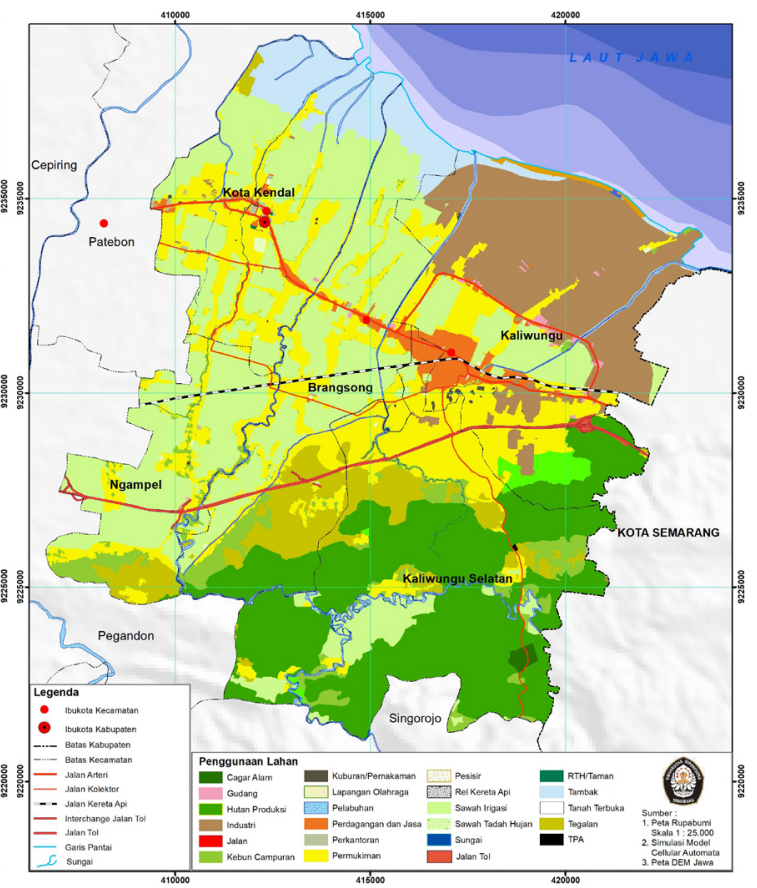

(b)

Gambar 8. Penggunaan lahan tahun 2017 (a) dan 2031 (b) di Kendal Timur Tabel 5. Perubahan Penggunaan Lahan Tahun 2017 - 2031

\begin{tabular}{llcccc}
\hline \multirow{2}{*}{ No } & \multirow{2}{*}{ Penggunaan Lahan } & \multicolumn{2}{c}{ Luas (Ha) } & \multicolumn{2}{c}{ Perkembangan 2017 - 2031 } \\
\cline { 3 - 6 } & & 2017 & 2031 & Ha & $\%$ \\
\hline 1 & Cagar Alam & 35,24 & 35,24 & 0 & 0,00 \\
2 & Gudang & 21,63 & 40,39 & 18,76 & 86,73
\end{tabular}




\begin{tabular}{|c|c|c|c|c|c|}
\hline 3 & Hutan Produksi & 3528,96 & 3527,64 & $-1,32$ & $-0,04$ \\
\hline 4 & Industri & 260,14 & 2278,1 & 2017,96 & 775,72 \\
\hline 5 & Jalan & 50,52 & 50,52 & 0 & 0,00 \\
\hline 6 & Kebun Campuran & 1135,15 & 772,81 & $-362,34$ & $-31,92$ \\
\hline 7 & Kuburan/Pemakaman & 16,71 & 16,71 & 0 & 0,00 \\
\hline 8 & Lapangan Olahraga & 29,01 & 29,01 & 0 & 0,00 \\
\hline 9 & Pelabuhan & 3,09 & 3,09 & 0 & 0,00 \\
\hline 10 & Perdagangan dan Jasa & 114,79 & 386,18 & 271,39 & 236,42 \\
\hline 11 & Perkantoran & 32,06 & 32,06 & 0 & 0,00 \\
\hline 12 & Permukiman & 2109,79 & 3117,09 & 1007,3 & 47,74 \\
\hline 13 & Pesisir & 52,22 & 52,22 & 0 & 0,00 \\
\hline 14 & Rel Kereta Api & 13,46 & 13,46 & 0 & 0,00 \\
\hline 15 & Sawah Irigasi & 5906,33 & 5121,98 & $-784,35$ & $-13,28$ \\
\hline 16 & Sawah Tadah Hujan & 245,8 & 179,09 & $-66,71$ & $-27,14$ \\
\hline 17 & Sungai & 233,22 & 233,22 & 0 & 0,00 \\
\hline 18 & RTH/Taman & 2,85 & 2,85 & 0 & 0,00 \\
\hline 19 & Tambak & 2515,41 & 921,87 & $-1593,54$ & $-63,35$ \\
\hline 20 & Tanah Terbuka & 147,05 & 1,55 & $-145,5$ & $-98,95$ \\
\hline 21 & Tegalan & 1470,08 & 1108,43 & $-361,65$ & $-24,60$ \\
\hline 22 & TPA & 1,65 & 1,65 & 0 & 0,00 \\
\hline 23 & Jalan Tol & 105,08 & 105,08 & 0 & 0,00 \\
\hline
\end{tabular}

Sumber : Hasil analisis, 2017

Perkembangan penggunaan lahan tahun 2031 di Kendal Timur cenderung terpusat di Kecamatan Kaliwungu dimana hasil perhitungan menunjukkan bahwa 75,32 \% atau seluas 2497,21 Ha dari total perkembangan penggunaan lahan terjadi di Kecamatan Kaliwungu. Hal ini tidak dapat dilepaskan karena merupakan lokasi ditetapkannya KIK dan sudah tumbuhnya Kawasan Perkotaan Kaliwungu dengan berbagai kelengkapan fasilitas yang ada. Adapun pola perkembangan kota di Kendal Timur berdasarkan hasil prediksi perubahan penggunaan lahan tahun 2017 - 2031 cenderung mengikuti pola perkembangan konsentris linier. Perkembangan terpusat di kawasan perkotaan Kaliwungu yang kemudian menyebar secara konsentris dan memanjang/linear mengikuti jalan. Hal ini dapat terlihat pada perkembangan permukiman dimana perkembangannya dari dari pusat kota yang kemudian menyebar secara konsentris kearah utara dan selatan (cenderung lebih luas ke arah selatan) mengarah ke Kecamatan Kaliwungu Selatan. Perkembangan permukiman juga mengikuti pola memanjang/linear yang mengikuti jalan terutama jalan arteri dan jalan lokal yang terjadi diseluruh kecamatan di Kendal Timur. Pola perkembangan konsentris linier ini juga terlihat pada perkembangan perdagangan dan jasa yang terpusat di kota Kecamatan Kaliwungu, menyebar secara konsentris dari perdagangan dan jasa eksisting yang kemudian berkembang ke arah arah barat mengikuti Jalan Arteri Kaliwungu Kendal dan ke arah timur mengikuti Jalan Raya Timur Kaliwungu yang menuju Kota Semarang. Berikut disajikan pola perkembangan kota di Kendal Timur (Gambar 9).

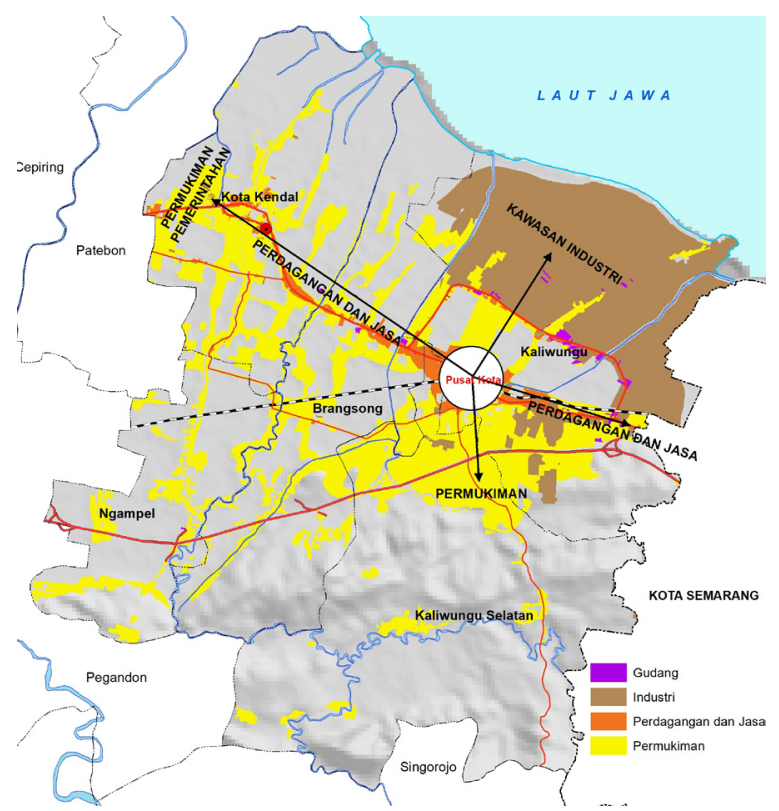

Gambar 9. Sebaran dan arah perkembangan Kendal Timur Tahun 2031

Berdasarkan analisis perubahan dan arah perkembangan di atas dapat dikatakan bahwa KIK berperan signifikan dalam pertumbuhan di Kendal 
Timur terutama di kawasan perkotaan kaliwungu. Akan tetapi yang perlu diperhatikan lebih lanjut yaitu bahwa pertumbuhan penggunaan lahan terbangun dalam hal ni permukiman dan perdagangan dan jasa tidak serta merta langsung tumbuh mendekati lokasi kawasan industri akan tetapi dalam proses pertumbuhannya dimulai dari pusat perkotaaan terdekat dalam hal ini Kawasan Perkotaan Kaliwungu. Hal ini tidak lepas bahwa dalam perubahan penggunaan lahan mempertimbangkan beberapa faktor pendorong meliputi biofisik, sosial ekonomi, sarana prasana, aksesibilitas dan ketetanggaan yang diturunkan menjadi 20 variabel pendorong dimana KIK menjadi salah satu variabel pendorongnya.

Kedekatan jarak dengan KIK sebagai variabel pendorong dan isu utama dalam penelitian ini ternyata tidak kemudian menjadi variabel pendorong utama (nilai pengaruh tertinggi) pada semua jenis penggunaan lahan yang berkembang, akan tetapi hanya pada industri dan gudang. KIK memiliki pengaruh yang sangat tinggi untuk perkembangan gudang dan industri, sedangkan untuk permukiman dan perdagangan dan jasa KIK bukan sebagai faktor pendorong yang memiliki nilai tertinggi. Pada pertumbuhan lahan gudang dari 20 variabel pendorong yang dianalisis, kedekatan jarak dengan KIK memiliki nilai pengaruh tertinggi yaitu sebesar 21,60 \% yang diikuti kedekatan jarak dengan pelabuhan sebesar 12,90 \% dan kedekatan dengan jarak interchange jalan tol sebesar 11,30\%. Pada perkembangan lahan industri kedekatan jarak dengan KIK memiliki pengaruh yang tinggi yaitu sebesar $24,10 \%$ yang diikuti kedekatan jarak dengan pelabuhan sebesar $15,00 \%$ dan kedekatan dengan jalan arteri sebesar $13,00 \%$. Pengaruh dominan kedekatan jarak dengan KIK untuk gudang dan industri tidak diikuti untuk perkembangan permukiman dan perdagangan dan jasa. Pada perkembangan permukiman dipengaruhi paling dominan yaitu kedekatan jarak dengan permukiman eksisting dengan nilai 16,40\%, diikuti kedekatan dengan jalan lokal sebesar 14,40\% dan kedekatan jarak ke pusat kota dengan sebesar 7,10\% sedangkan kedekatan jarak dengan KIK untuk perkembangan permukiman memiliki nilai pengaruh yang dapat dikatakan sedang yaitu sebesar $4,90 \%$. Pada perkembangan perdagangan dan jasa variabel pendorong yang dominan berpengaruh terhadap perubahan penggunaan lahan perdagangan dan jasa yaitu jalan arteri sebesar 22,40\%, diikuti dengan kedekatan jarak dengan perdagangan dan jasa eksisting sebesar 17,80\% dan kedekatan jarak dengan jalan kolektor sebesar 7,80\%, sedangkan kedekatan dengan KIK memiliki pengaruh yang dapat dikatakan sedang dengan sebesar $4,10 \%$.

\section{KESIMPULAN}

Berdasarkan hasil penelitian yang telah dilakukan dapat dihasilkan kesimpulan bahwa model cellular automata mampu melakukan prediksi penggunaan lahan tahun 2031 di Kendal Timur dengan adanya pengaruh pembangunan KIK dengan tingkat akurasi model 95,68 \%. Kedekatan jarak dengan KIK berpengaruh kuat terhadap arah perkembangan industri dengan besar pengaruh $24,10 \%$, arah perkembangan gudang dengan besar pengaruh $21,60 \%$, tidak terlalu kuat arah perkembangan permukiman dengan besar pengaruh $4,90 \%$ dan arah perkembangan perdagangan dan jasa dengan besar pengaruh $4,10 \%$. Perkembangan permukiman dan perdagangan dan jasa dimasa depan dengan adanya kawasan industri tidak serta merta langsung mendekati lokasi kawasan industri tersebut akan tetapi masih mempertimbangkan faktor sosial ekonomi, aksesbilitas, sarana dan prasarana dan ketetanggaan sehingga memiliki kecenderungan perkembangannya dimulai dari titik kota (kecamatan) yang terdekat dengan lokasi kawasan industri. Hasil prediksi penggunaan lahan tahun 2031 di Kendal Timur menunjukkan terdapat empat penggunaan lahan yang mengalami pertumbuhan pada tahun 2031 meliputi, industri $(2017,96 \mathrm{Ha})$, permukiman $(1007,30$ $\mathrm{Ha})$, perdagangan dan jasa $(271,39 \mathrm{Ha})$, dan gudang $(18,76 \mathrm{Ha})$. Adapun penggunaan lahan yang terkonversi menjadi lahan terbangun yaitu tambak (1.593,54 Ha), sawah irigasi (784,35 Ha), kebun campuran (362,34 Ha), tegalan $(361,65 \mathrm{Ha})$, tanah terbuka $(145,5 \mathrm{Ha})$, sawah tadah hujan $(66,71 \mathrm{Ha})$ dan hutan produksi $(1,32 \mathrm{Ha})$. Perkembangan penggunaan lahan tahun 2031 terbesar terjadi di Kecamatan Kaliwungu dengan luas 2497,21 Ha atau 75,32 \% dari total perkembangan penggunaan lahan di Kendal Timur. Adapun arah perkembangannya mengikuti pola perkembangan konsentris linier yang dimulai dari pusat Kecamatan Kaliwungu. Potensi perkembangan penggunaan lahan dengan adanya pembangunan kawasan industri ini harus diakomodir dalam Rencana Pola Ruang Kabupaten Kendal terutama pada kawasan perkotaan kaliwungu agar tidak terjadi perkembangan lahan yang sporadik dan acak yang dapat mengancam lahan pertanian produktif.

\section{UCAPAN TERIMA KASIH}

Penulis mengucapkan terima kasih kepada pihak yang telah membantu dalam proses penulisan utamanya pihak Pusbindiklatren Bappenas atas kesempatan yang diberikan dan dukungannya dalam beasiswa Pendidikan Magister di program Magister Pembangunan Wilayah dan Kota (MPWK) Universitas Diponegoro, dan Kementerian Agraria dan Tata Ruang (ATR/BPN) dan Kantor Pertanahan Kabupaten Badung atas dukungan dan penugasan untuk tugas belajar.

\section{DAFTAR PUSTAKA}

Anderson, G., \& Ge, Y. (2004). Do Economic Reforms Accelerate Urban Growth? The Case of China. Urban Studies, 41(4100000732), 2211-2230.

Bogaert, P., \& Dendoncker, N. (2007). Spatial analysis and modelling of land use distributions in Belgium Spatial analysis and modelling of land use distributions in Belgium. Computers, Environment 
and Urban Systems,31(April2015), 188-205.https:// doi.org/10.1016/j.compenvurbsys.2006.06.004

Camagni, R., Gibelli, M. C., \& Rigamonti, P. (2002). Urban mobility and urban form: the social and environmental costs of different patterns of urban expansion. Ecological Economics, 40(2), 199-216. https://doi.org/http://dx.doi.org/10.1016/S09218009(01)00254-3

Cohen, B. (2004). Urban Growth in Developing Countries: A Review of Current Trends and a Caution Regarding Existing Forecasts. World Development, 32(1), 23-51.

Dadras, M., Shafri, H. Z. M., Ahmad, N., Pradhan, B., \& Safarpour, S. (2015). Spatio-temporal analysis of urban growth from remote sensing data in Bandar Abbas city, Iran. Egyptian Journal of Remote Sensing and Space Science, 18(1), 35-52. https:// doi.org/10.1016/j.ejrs.2015.03.005

Damayanti, R. (2010). Pertumbuhan Fisik Kota Karena Pengaruh Industrialisasi, studi kasus Kota Ahmedabad - India. Humanisme, Arsitektur Dan Perencanaan.

Danoedoro, P. (2006). Extracting Land-Use Information Related to Socio-Economic Function From Quickbird Imagery: A Case Study of Semarang Area, Indonesia. In Map Asia, Bangkok (Vol. 1). Bangkok.

Guan, D., Li, H., Inohae, T., Su, W., Nagaie, T., \& Hokao, K. (2011). Modeling urban land use change by the integration of cellular automaton and Markov model. Ecological Modelling, 222(20-22), 3761-3772. https://doi.org/10.1016/j. ecolmodel.2011.09.009

Han, H., Yang, C., \& Song, J. (2015). Scenario Simulation and the Prediction of Land Use and Land Cover Change in Beijing, China. Sustainability, 7, 42604279. https://doi.org/10.3390/su7044260

Hosseinali, F., Alesheikh, A. A., \& Nourian, F. (2013). Agent-based modeling of urban landuse development, case study: Simulating future scenarios of Qazvin city. Cities, 31, 105-113. https:// doi.org/10.1016/j.cities.2012.09.002

Leao, S., Bishop, I., \& Evans, D. (2014). Simulating Urban Growth in a Developing Nation 's Region Using a Cellular Automata- Based Model. Journal of Urban Planning and Development, (July). https:// doi.org/10.1061/(ASCE)0733-9488(2004)130

Liu, Y. (2009). Modelling Urban Development with Geographical Information System and Cellular Automata. Boca Raton: CRC Press.

Liu, Y., \& He, J. (2009). Developing a web-based cellular automata model for urban growth simulation, 7492, 1-8. https://doi.org/10.1117/12.838657

Maria, R., Omrani, H., Charif, O., \& Gerber, P. (2014). Land use changes modelling using advanced methods : Cellular automata and artificial neural networks. The spatial and explicit representation of land cover dynamics at the cross-border region scale. Applied Geography, 53, 160-171. https://doi. org/10.1016/j.apgeog.2014.06.016

Milad, M., Ming, Y., Firuz, M., \& Hanan, Z. (2016). The simulation and prediction of spatio-temporal urban growth trends using cellular automata models : A review. International Journal of Applied Earth Observations and Geoinformation, 52, 380389. https://doi.org/10.1016/j.jag.2016.07.007

Pawan. (2016). Urbanization and Its Causes and Effects : A Review. International Journal of Research and Scientific Innovation (IJRSI), III(Ix), 110-112. https://doi.org/10.1038/sdata.2016.34.ISSN

Pratomoatmojo, N. A. (2014). LanduseSim sebagai aplikasi pemodelan dan simulasi spasial perubahan penggunaan lahan berbasis Sistem Informasi Geografis dalam konteks perencanaan wilayah dan kota. Seminar Nasional Cities, 69-80.

Purwadhi, S.H., (2001). Interpretasi Citra Digital. Jakarta : Grasindo.

Santé, I., García, A. M., Miranda, D., \& Crecente, R. (2010). Landscape and Urban Planning Cellular automata models for the simulation of real-world urban processes: A review and analysis. Landscape and Urban Planning, 96, 108-122. https://doi. org/10.1016/j.landurbplan.2010.03.001

Tian, L., Ge, B., \& Li, Y. (2017). Impacts of state-led and bottom-up urbanization on land use change in the peri-urban areas of Shanghai: Planned growth or uncontrolled sprawl? Cities, 60, Part B, 476486. https://doi.org/http://dx.doi.org/10.1016/j. cities.2016.01.002

Torrens, P. M. (2003). Automata $\nabla$ based models of urban systems. In In Advanced Spatial Analysis, $P$. Longley \& M. Batty (Eds.) (pp. 61-79). Redlands: ESRI Press.

Wardana, D. W., Danoedoro, P., \& Susilo, B. (2016). Kajian Perubahan Penggunaan Lahan Berbasis Citra Satelit Penginderaan Jauh Resolusi Menengah Dengan Metode Multi Layaer Perceptron dan Markov Chain. Majalah Geografi Indonesia, 30(1), 9-18.

Wolfram, S. (1984). Cellular automata as simple selforganizing systems. Elsevier Science Publishers B.V. Retrieved from http://cds.cern.ch/record/140047 